Int. J. Electrochem. Sci., 14 (2019) $3752-3763$

International Journal of

ELECTROCHEMICAL

SCIENCE

www.electrochemsci.org

\title{
An Investigation on Structural, Electrical and Optical properties of GO/ZnO Nanocomposite
}

\author{
Virginia Mututu, Sunitha A K, Riya Thomas, Mayank Pandey, Manoj B* \\ Department of Physics \& Electronics, CHRIST (Deemed to be University), Bengaluru, Karnataka, \\ India \\ "E-mail: manoj.b@ christuniversity.in
}

doi: $10.20964 / 2019.04 .49$

Received: 28 August 2018/ Accepted: 20 October 2018 / Published: 10 March 2019

\begin{abstract}
Coupling of graphene oxide with metal oxide is an effective way to enhance the opto-electric properties of the composite. Herein, a hybrid structure of graphene oxide (GO) -Zinc oxide ( $\mathrm{ZnO}$ ) nanostructure was successfully designed and fabricated with varying concentrations of $\mathrm{ZnO}$. The $\mathrm{GO}$ and $\mathrm{ZnO}$ nanoparticles were synthesized through Hummer's and simple precipitation method respectively. Structural and physiochemical properties were examined via X-ray powder diffraction, FTIR and UVVis spectroscopy. The XRD results of GO showed a peak at $2 \theta$ of $12.02^{\circ}$ with particles of size $6 \mathrm{~nm}$ and inter layer spacing $0.87 \mathrm{~nm}$. The XRD patterns of $\mathrm{ZnO}$ nanoparticles showed a hexagonal unit cell structure and the average dimension of the sample was calculated to be $15 \mathrm{~nm}$. The band gap of the synthesized GO is found to be $5.1 \mathrm{eV}$ and that of $\mathrm{ZnO}$ to be $3.07 \mathrm{eV}$ with the help Tauc plot. The dependence of various concentration of $\mathrm{ZnO}$ on the electrical behaviour is discussed by an impedance analyzer in the frequency range $100 \mathrm{~Hz}$ to $1 \mathrm{MHz}$. The $\mathrm{ZnO} / \mathrm{GO}$ composite with best results have been obtained for $20 \%$ and $60 \%$ ratios of $\mathrm{ZnO}$. The composite has high dielectric permittivity and low loss tangent values and is identified as a promising candidate for energy storage applications.
\end{abstract}

Keywords:Nanocomposite, Graphene oxide, Tin oxide, physiochemical properties.

\section{$\underline{\text { FULL TEXT }}$}

(C) 2019 The Authors. Published by ESG (www.electrochemsci.org). This article is an open access article distributed under the terms and conditions of the Creative Commons Attribution license (http://creativecommons.org/licenses/by/4.0/). 